\title{
Metabolism of 1,25-Dihydroxycholecalciferol in the Rat
}

\author{
Charles A. Frolik and Hector F. Deluca \\ From the Department of Biochemistry, College of Agricultural and Life \\ Sciences, University of Wisconsin, Madison, Wisconsin 5.3706
}

A B S TRACT Administration of 60 pmoles of 1.25-dihydroxycholecalciferol to vitamin D-deficient rats on a low calcium diet gives a maximal intestinal calcium transport response in $7 \mathrm{hr}$ and a maximal bone calcium mobilization response in $12 \mathrm{hr}$. During the $48 \mathrm{hr}$ after injection of radioactive 1.25-dihydroxycholecalciferol, unchanged 1,25-dihydroxycholecalciferol accounts for $71-$ $98 \%$ of the radioactivity found in the intestine with minor amounts appearing in more polar metabolites. In the bone, for the 1 st $12 \mathrm{hr}, 1,25$-dihydroxycholecalciferol is the major form $(75-82 \%)$ present while at $24 \mathrm{hr}$, the amount of 1,25-dihydroxycholecalciferol decreases with a corresponding rise in the amounts of metabolites both less polar and more polar than the 1,25-dihydroxycholecalciferol. Since these metabolies are at their highest concentration when bone calcium mobilization is decreasing. they are most likely not responsible for the calcium mobilization observed during the 1 st $12 \mathrm{hr}$. The appearance of water-soluble radioactivity in the kidney, plasma. liver, and muscle $24 \mathrm{hr}$ after 1.25-dihydroxycholecalciferol injection has been demonstrated. The present results suggest that, although 1.25-dihydroxycholecalciferol is converted to further metabolites in the rat. it is probably the form of vitamin $\mathrm{D}$ responsible for initiating intestinal calcium transport and bone calcium mobilization.

\section{INTRODUCTION}

That vitamin $\mathrm{D}$ must be metabolized to polar metabolites before it can function is an idea that has been developed during the past few years. This idea obtained a firm foothold with the demonstration that, after a $10 \mathrm{IL}$ dose of vitamin $\mathrm{D}_{3}{ }^{3} \mathrm{H}$ to a rat, there appeared a major polar metabolite fraction that retained the biological activity of the parent ritamin (1). This metabolite has since been isolated and identified as 25-hydroxycholecalciferol (25$\left.\mathrm{OHD}_{3}\right)^{1}(2)$. It is not, however, the final metabolically

\footnotetext{
Receized for publication 19 May 1972 and in reised form 5 July 19i2.

${ }^{1}$ Abbreviations used in this paper: 25-OHD: 25-hydroxycholecalciferol ; 1,25-(OH).:D:, 1,25-dihydroxycholecalciferol.
}

active form of vitamin $D$. Recent experiments have shown that the kidney sequesters the circulating $25-\mathrm{OHD}_{3}$ and converts it to more polar metabolites $(3,4)$, the most important of which has been unequivocally identified as $1,25-(\mathrm{OH})_{2} \mathrm{D}_{3}(5,6)$. Supporting evidence for this structure was provided independently by Lawson, Fraser, Kodicek, Morris, and Williams with partially purified material from kidney homogenates (7).

The question as to whether $1,25-(\mathrm{OH})_{2} \mathrm{D}_{3}$ is the final tissue active metabolite of vitamin $\mathrm{D}$ now becomes apparent. In the intestine, $1.25-(\mathrm{OH})_{2} \mathrm{D}_{3}$ has been shown to act more rapidly than $25-\mathrm{OHD}_{3}$ in initiating calcium transport $(8,9)$. Furthermore, in contrast to the 25$\mathrm{OHD}_{3}$ response, the intestinal calcium absorption stimulation by $1,25-(\mathrm{OH})_{2} \mathrm{D}_{3}$ is not blocked by prior administration of actinomycin D (10). Recently, it has also been shown in chicks that, at the time when intestinal calcium transport has reached a maximal rate in response to $1,25-(\mathrm{OH})_{2} \mathrm{D}_{3}$, only this metabolite is detectable in the intestine (11). Furthermore, in nephrectomized rats, the intestine responds only to $1.25-(\mathrm{OH})_{2} \mathrm{D}_{3}$ and not to $25-\mathrm{OHD}_{3}$ (12). It therefore appears that, at least in the chick, $1,25-(\mathrm{OH})_{2} \mathrm{D}_{3}$, and not a further metabolite, is the active form of vitamin $\mathrm{D}$ in initiating the intestinal calcium transport system.

Like the intestinal response, there is a quicker induction of the bone calcium mobilization system after 1,25$(\mathrm{OH})_{2} \mathrm{D}_{3}$ than after an equivalent dose of $25-\mathrm{OHD}$, (13). Also, in fetal bone tissue cultures, $1.25-(\mathrm{OH})_{2} \mathrm{D}_{3}$ will cause bone calcium mobilization at concentrations much less than 25- $\mathrm{OHD}_{3}$ (14). However, in contrast to the intestine, the bone calcium mobilization response to both $1,25-(\mathrm{OH})_{2} \mathrm{D}_{3}$ and to $25-\mathrm{OHD}_{3}$ is actinomycin $\mathrm{D}$ sensitive (13). Finally, it has been demonstrated that anephric rats show a bone calcium mobilization response to $1.25-(\mathrm{OH}): \mathrm{D}_{3}$ but not to 25-OHD: (15) eliminating the latter as the physiologically active form of vitamin $D$ in this system.

This report demonstrates that in the rat, as well as in the chick, it is $1.25-(\mathrm{OH})_{2} \mathrm{D}_{3}$ and not a further metabolite that is responsible for increased intestinal cal- 
cium transport. Indications also point to the idea that $1,25-(\mathrm{OH})_{2} \mathrm{D}_{3}$ is the active form of vitamin $\mathrm{D}$ in the bone, although further metabolism of $1,25-(\mathrm{OH})_{2} \mathrm{D}_{3}$ does occur.

\section{METHODS}

Animals. Weanling male albino rats (Holtzman Co., Madison, Wis.) were housed in individual hanging wire cages. They were fed ad lib. a vitamin D-deficient diet, low in calcium $(0.02 \%)$ and adequate in phosphorous $(0.3 \%)$ (16) for 2-3 wk.

Radioactive 1,25-dihydroxycholecalciferol. $\quad\left[26,27-{ }^{2} \mathrm{H}\right]-1$, $25-(\mathrm{OH})_{2} \mathrm{D}_{3}$ was synthesized from $\left[26,27-{ }^{3} \mathrm{H}\right]-25-\mathrm{OHD}_{3}(1.2$ $\mathrm{Ci} / \mathrm{mmole}$ ) (17) using the in vitro chick kidney incubation system previously described by Gray, Boyle, and DeLuca (4) as modified by Boyle, Miravet, Gray, Holick, and DeLuca (12). Before injection of this $\left[26,27-{ }^{3} \mathrm{H}\right]-1,25-(\mathrm{OH})_{2^{-}}$ $\mathrm{D}_{3}$ into the experimental animal, the dose was chromatographed on a Sephadex LH-20 column (Pharmacia Fine Chemicals, Inc., Piscataway, N. J.) (chloroform: Skellysolve B [petroleum ether redistilled at bp $67-68^{\circ} \mathrm{C}$, Skelly Oil Co., Tulsa, Okla.] : methanol, $75: 23: 2$ ) as described previously (11) to determine purity. In all cases, the 1,25$(\mathrm{OH})_{2} \mathrm{D}_{3}$ was the only peak eluted from this column. It accounted for $98 \pm 5 \%$ of the applied radioactivity.

Experimental procedure: metabolism experiments. Rats were injected intrajugularly with $59.6 \pm 7.5$ pmoles of $[26$, $\left.27-{ }^{3} \mathrm{H}\right]-1,25-(\mathrm{OH})_{2} \mathrm{D}_{3}$ dissolved in $0.05 \mathrm{ml}$ of $95 \%$ ethanol. After the required time interval, the animals were sacrificed. Plasma obtained from each rat was separated from the heparinized blood by centrifugation and its radioactivity determined (11). The plasma from all rats at each time point was then combined. The first $50 \mathrm{~cm}$ of the small intestine were removed, washed in saline, split open, and washed again. The mucosa was then scraped off with a microscope slide. In addition, the kidneys, liver, both the hind- and forelegs, and a sample of muscle were removed. The individual tissues from all the rats in a group at a particular time point were pooled.

Plasma and $20 \%$ homogenates in water of the intestinal mucosa, kidney, and liver were extracted and counted as described earlier (11). The hind- and forelegs were dissected free from adhering muscle and ligaments, split lengthwise to facilitate removal of bone marrow, and weighed. The bone sections were then allowed to cool on solid $\mathrm{CO}_{2}$ and pulverized in a mortar and pestle maintained near the temperature of the solid $\mathrm{CO}_{2}$. The frozen, pulverized bone was immediately mixed with $200 \mathrm{ml}$ of methanol-chloroform $(2: 1, v / v)$ and stirred overnight under $\mathrm{N}_{2}$ and at $4^{\circ} \mathrm{C}$. A portion of the final solution was counted (11). This measurement was taken to be the radioactivity present in the whole tissue. Then $100 \mathrm{ml}$ of chloroform and $80 \mathrm{ml}$ of distilled water were added to separate the phases. The water phase was reextracted with $100 \mathrm{ml}$ of chloroform and the two chloroform layers combined and samples counted. The muscle was frozen, ground, and extracted by a similar method. The amount of radioactivity in the water phase was determined by subtracting the chloroformsoluble radioactivity from the radioactivity found in the whole homogenate before extraction.

Chromatography. The chloroform layers from the tissue extracts were evaporated with a flash evaporator and the lipid that remained behind after removal of the residual water as an azeotrope with $100 \%$ ethanol was redissolved in chloroform: Skellysolve B:methanol $(75: 23: 2)$. The sample was applied to the Sephadex LH-20 column described previously (11) with the only modification being the use of chloroform: methanol $(1: 1)$ to strip the column. A typical chromatographic profile showing the various metabolite peaks observed in bone and intestine $24 \mathrm{hr}$ after injection of $1,25-(\mathrm{OH}){ }_{2} \mathrm{D}_{3}$ is shown in Fig. 1 .

Intestinal calcium transport measurement. Calcium transport was studied using the everted gut sac technique adapted for calcium by Schachter and Rosen and modified by Martin and DeLuca (18). The results from four to five rats were averaged for each time point indicated.

Bone calcium mobilization assay. Rats were divided into two groups of from six to eight animals each. Each rat was then given an intrajugular injection of either $0.05 \mathrm{ml}$ $95 \%$ ethanol or $0.05 \mathrm{ml} 95 \%$ ethanol containing 60 pmoles of $\left[26,27-{ }^{3} \mathrm{H}\right]-1,25(\mathrm{OH})_{2} \mathrm{D}_{3}$. After injection the groups were divided into two subgroups. The first group had about 0.5

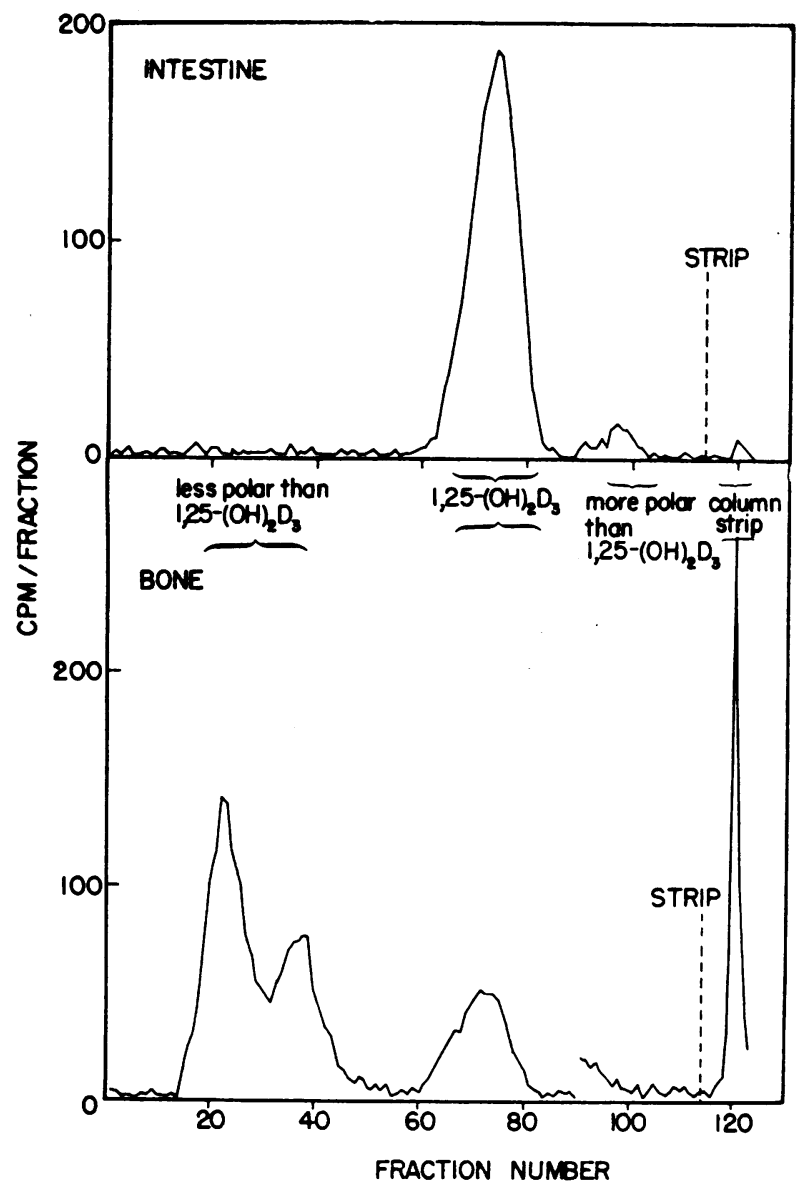

FIgURE 1 Chromatography of the lipid extracts of intestinal mucosa and bone taken $24 \mathrm{hr}$ after rats had received $59.6 \pm 7.5$ pmoles of $\left[26,27-{ }^{3} \mathrm{H}\right]-1,25(\mathrm{OH})_{2} \mathrm{D}_{3}$. Chromatography was carried out on a Sephadex LH-20 column $(1 \times$ $53 \mathrm{~cm}$ ) packed in and eluted with chloroform: Skellysolve B : methanol $(75: 23: 2, \mathrm{v} / \mathrm{v})$. The column was stripped at fraction number 114 with chloroform: methanol $(1: 1)$. 1,25$(\mathrm{OH})_{2} \mathrm{D}_{3}$ refers to 1,25 -dihydroxycholecalciferol. The remaining metabolites are referred to by their elution position relative to $1,25-(\mathrm{OH})_{2} \mathrm{D}_{3}$. 


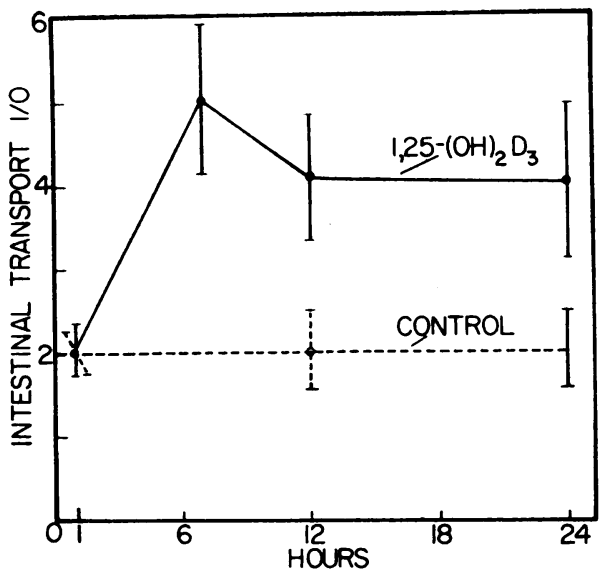

FIgURE 2 Time-course study of intestinal calcium transport as measured by the everted gut sac technique. In this test the duodenum (upper $5 \mathrm{~cm}$ ) is removed, everted, and tied at both ends. The inside (serosal surface) is filled with medium containing ${ }^{45} \mathrm{Ca}$ and the sac is incubated for $1 \frac{1}{\mathrm{hr}}$ in the same medium under an atmosphere of $95 \% \quad \mathrm{O}_{2}: 5 \%$ $\mathrm{CO}_{2}$. At the end of the incubation period the ${ }^{45} \mathrm{Ca}$ in both the serosal and mucosal media are measured and the data are expressed as a ratio of ${ }^{45} \mathrm{Ca}$ on the serosal side (I) to the ${ }^{45} \mathrm{Ca}$ on the mucosal side $(0)$. Each time point represents the average \pm standard deviation of the results from four to five vitamin D-deficient rats on a low calcium diet injected intrajugularly with either 60 pmoles of 1,25$(\mathrm{OH})_{2} \mathrm{D}_{3}$ in $0.05 \mathrm{ml} 95 \%$ ethanol or with the ethanol vehicle only.

$\mathrm{ml}$ of blood withdrawn through the tail vein at 1,24 , and $72 \mathrm{hr}$ after dosages while the second group had $0.5 \mathrm{ml}$ blood removed at 6,48 , and $72 \mathrm{hr}$ postinjection. This experiment was repeated with a group of rats from a different litter and with a dose prepared at a different time. Additional 1

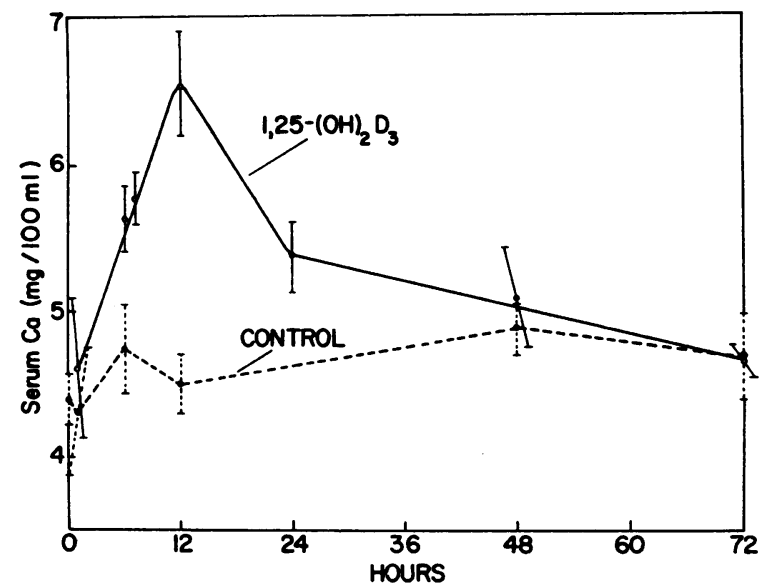

Figure 3 Time-course study of the bone calcium mobilization response of vitamin D-deficient rats on a low calcium diet to intrajugular administration of either 60 pmoles 1,25$(\mathrm{OH})_{2} \mathrm{D}_{3}$ in $0.05 \mathrm{ml} 95 \%$ ethanol or the ethanol vehicle only. Each time point represents the average \pm standard deviation of the results from 5-13 rats. Serum calcium concentration was determined by atomic absorption spectrometry.
TABLE I

Metabolites in Intestinal Mucosa after Injection of $\left[26,27-{ }^{3} \mathrm{H}\right]-1,25-D i h y d r o x y$ cholecalciferol

\begin{tabular}{|c|c|c|c|c|c|c|}
\hline \multirow[b]{2}{*}{$\begin{array}{l}\text { Time } \\
\text { after } \\
\text { dose }\end{array}$} & \multicolumn{6}{|c|}{ Metabolites } \\
\hline & $\begin{array}{c}\text { Less } \\
\text { polar } \\
\text { than } \\
1,25- \\
(\mathrm{OH})_{2} \mathrm{D}_{3} *\end{array}$ & $\begin{array}{c}1,25- \\
(\mathrm{OH})_{2} \mathrm{D}_{3} *\end{array}$ & $\begin{array}{l}\text { More polar } \\
\text { than } 1,25- \\
(\mathrm{OH})_{2} \mathrm{D}_{3} *\end{array}$ & $\begin{array}{l}\text { Column } \\
\text { strip }\end{array}$ & $\begin{array}{c}\mathrm{H}_{2} \mathrm{O} \\
\text { soluble }\end{array}$ & $\begin{array}{l}\text { Total } \\
\text { recovery }\end{array}$ \\
\hline$h r$ & \multicolumn{6}{|c|}{$\%$ of homogenate radioactivily } \\
\hline 1 & - & 98 & 一 & 1.9 & $\mathbf{0}$ & 99.9 \\
\hline 7 & - & 89 & 1.6 & 0.6 & 3 & 94.2 \\
\hline 12 & - & 71 & 3.5 & 1.0 & 13 & 88.5 \\
\hline 24 & - & $84 \pm 7 \ddagger$ & $3.3 \pm 0.1$ & $2.7 \pm 2.1$ & $7 \pm 7$ & $97.0 \pm 3.1$ \\
\hline 48 & - & 79 & 1.6 & 0.5 & 7 & 88.1 \\
\hline
\end{tabular}

For each time point, three to five vitamin D-deficient rats on a low calcium diet were dosed intrajugularly with $59.6 \pm 7.5$ pmoles of $\left[26,27-{ }^{3} \mathrm{H}\right]-1$, $25-(\mathrm{OH})_{2} \mathrm{D}_{3}$.* At the times indicated the rats were killed and intestinal mucosa from the first $50 \mathrm{~cm}$ of small intestine pooled for each group and analyzed for metabolities as described in the text.

$* 1,25-(\mathrm{OH})_{2} \mathrm{D}_{3}, 1,25$-dihydroxycholecalciferol.

† Standard deviation.

and $24 \mathrm{hr}$ data, plus the values for the 7 and $12 \mathrm{hr}$ points were obtained from the four to five rats used for the intestinal calcium transport assay. Blood was collected from these rats by decapitation. For each time point, the results from the three experiments were averaged and standard deviations determined. To determine the serum calcium, the blood samples were immediately centrifuged and $0.1 \mathrm{ml}$ serum was mixed with $1.9 \mathrm{ml}$ of $0.1 \% \mathrm{LaCl}_{3}$. The calcium concentration was determined with a Perkin-Elmer atomic absorption spectrometer model 403 (Perkin-Elmer Corp., Norwalk, Conn.).

Radioactive measurcments. Radioactivity in the tissue homogenates, plasma, chloroform-soluble phases, and column effluents were determined as previously described (11). The samples were counted in a Packard Tri-Carb liquid scintillation counter, model 3003 (Packard Instrument Co., Inc., Downers Grove, Ill.) equipped with an automatic external standardization system.

\section{RESULTS}

Biological activity. The response of the intestinal calcium transport system to 60 pmoles of $1,25-(\mathrm{OH})_{2} \mathrm{D}_{3}$ is

TABLE II

Concentration of 1,25-Dihydroxycholecalciferol in Intestinal Mucosa after Injection of $\left[26,27-{ }^{3} \mathrm{H}\right]-1$, 25-Dihydroxycholecalciferol

\begin{tabular}{lccccc}
\hline & \multicolumn{5}{c}{ Hours after dosage } \\
\cline { 2 - 6 } & 1 & 7 & 12 & 24 & 48 \\
\hline $\begin{array}{l}\text { Picomoles 1, } \\
\text { 25- }(\mathrm{OH})_{2} \mathrm{D}_{3}{ }^{*} \text { per } \\
\text { gram mucosa }\end{array}$ & 1.54 & 1.83 & 0.87 & $0.95 \pm 0.11 \ddagger$ & 0.36
\end{tabular}

The animals were treated as described in Table $\mathrm{I}$.

* 1,25- $(\mathrm{OH})_{2} \mathrm{D}_{3}, 1,25$-dihydroxycholecalciferol.

$\ddagger$ Standard deviation. 
shown in Fig. 2. It is clear that by $7 \mathrm{hr}$ after dosage, the transport ratio of the experimental animals is significantly above the values of the controls. Examination of the bone calcium mobilization response to a similar dose of $1,25-(\mathrm{OH})_{2} \mathrm{D}_{3}$ shows a maximal response at $12 \mathrm{hr}$ after injection (Fig. 3). It is interesting to note that the effect of $1,25-(\mathrm{OH})_{2} \mathrm{D}_{3}$ in the bone is short in duration with serum calcium values returning to control values $48 \mathrm{hr}$ after dosage.

Metabolites of $1,25-(\mathrm{OH})_{2} D_{3}$ in intestine and bone. As the results in Table I demonstrate, from 1 to $48 \mathrm{hr}$ after injection, $1,25-(\mathrm{OH})_{2} \mathrm{D}_{3}$ is the major metabolite appearing in the intestine, accounting for from 71 to $98 \%$ of the radioactivity in the intestinal homogenate. The remainder of the intestinal radioactivity is distributed among several peaks more polar than the $1,25-(\mathrm{OH})_{2} \mathrm{D}_{3}$ and in the water layer left after extraction. The more polar radioactivity is small in amount and reaches a maximum at 12-24 hr after injection. Note that at $1 \mathrm{hr}$ after $1,25-(\mathrm{OH})_{2} \mathrm{D}_{3}$ intestinal calcium transport remains unchanged from control values (Fig. 2), while the $1,25-(\mathrm{OH})_{2} \mathrm{D}_{3}{ }_{-}{ }^{3} \mathrm{H}$ is certainly present in intestine at that time (Table II), revealing a definite lag in the action of $1,25-(\mathrm{OH}){ }_{2} \mathrm{D}_{3}$ on intestinal calcium transport.

In bone from 1 to $12 \mathrm{hr}$ after injection of 1,25 $(\mathrm{OH})_{2} \mathrm{D}_{3}$, that is when the bone calcium mobilization response is maximal, $75-82 \%$ of the bone radioactivity is present as $1,25-(\mathrm{OH})_{2} \mathrm{D}_{3}$ (Table III). However, at 24 $\mathrm{hr}$, the time when the bone calcium mobilization response is beginning to decline, the metabolite picture changes sharply. There is a drop in the per cent of bone radioactivity appearing in the $1,25-(\mathrm{OH})_{2} \mathrm{D}_{3}$ region of the column effluent and a corresponding increase in radioactivity appearing in two peaks less polar than 1,25$(\mathrm{OH})_{2} \mathrm{D}_{3}$. At $48 \mathrm{hr}$, there was not a sufficient amount

TABLE III

Metabolites in Bone after Injection of $\left[26,27-{ }^{3} \mathrm{H}\right]-1$, 25-Dihydroxycholecalciferol

\begin{tabular}{|c|c|c|c|c|c|c|}
\hline \multirow[b]{2}{*}{$\begin{array}{l}\text { Time } \\
\text { after } \\
\text { dose }\end{array}$} & \multicolumn{6}{|c|}{ Metabolites } \\
\hline & $\begin{array}{l}\text { Less polar } \\
\text { than } 1,25- \\
(\mathrm{OH})_{2} \mathrm{D}_{3} *\end{array}$ & $\begin{array}{c}1,25- \\
(\mathrm{OH})_{2} \mathrm{D}_{3}\end{array}$ & $\begin{array}{l}\text { More polar } \\
\text { than } 1,25- \\
(\mathrm{OH})_{2} \mathrm{D}_{3} *\end{array}$ & $\begin{array}{l}\text { Column } \\
\text { strip }\end{array}$ & $\begin{array}{c}\mathrm{H}_{2} \mathrm{O} \\
\text { soluble }\end{array}$ & $\begin{array}{l}\text { Total } \\
\text { recovery }\end{array}$ \\
\hline$h r$ & \multicolumn{6}{|c|}{$\%$ of homogenale radioactivity } \\
\hline 1 & 4.9 & 82 & - & 1.8 & 0 & 88.7 \\
\hline 7 & 1.1 & 77 & 1.2 & 1.2 & 9 & 89.5 \\
\hline 12 & 2.7 & 75 & 3.6 & 1.8 & 0 & 83.1 \\
\hline 24 & $23 \pm 4 ; \ddagger 11 \pm 4$ & $25 \pm 11$ & $1.3 \pm 1.3$ & $8.0 \pm 1.6$ & $6 \pm 1$ & $72.5 \pm 4.1$ \\
\hline
\end{tabular}

For each time point, three to five vitamin D-deficient rats on a low calcium diet were dosed intrajugularly with $59.6 \pm 7.5$ pmoles of $\left[26,27-{ }^{3} \mathrm{H}\right]-1$, $25-(\mathrm{OH})_{2} \mathrm{D}_{3}$.* At the times indicated the rats were killed and the fore- and hindlimbs pooled for each group and analyzed for metabolites as described in the text.

$* 1,25-(\mathrm{OH})_{2} \mathrm{D}_{3}, 1,25$-dihydroxycholecalciferol.

$\ddagger$ Standard deviation.
TABLE IV

Concentration of 1,25-Dihydroxycholecalciferol in Bone after Injection of $\left[26,27-{ }^{3} \mathrm{H}\right]-1,25-D$ ihydroxycholecalciferol

\begin{tabular}{lcccc}
\hline & \multicolumn{5}{c}{ Hours after dosage } \\
\cline { 2 - 5 } & 1 & 7 & 12 & 24 \\
\hline $\begin{array}{c}\text { Picomoles 1,25- }(\mathrm{OH})_{2} \mathrm{D}_{3}{ }^{*} \\
\text { per gram bone }\end{array}$ & 0.74 & 0.70 & 0.38 & $0.28 \pm 0.08 \ddagger$
\end{tabular}

The animals were treated as described in Table III.

* 1,25- $(\mathrm{OH})_{2} \mathrm{D}_{3}, 1,25$-dihydroxycholecalciferol.

$\ddagger$ Standard deviation.

of radioactivity in the bone to permit chromatography of the chloroform extract. Table IV gives the concentration of $1,25-(\mathrm{OH})_{2} \mathrm{D}_{3}$ in the bone. At $12 \mathrm{hr}$ when the bone calcium mobilization response is maximum there is already a decrease in the concentration of $1,25-(\mathrm{OH})_{2} \mathrm{D}_{3}$ present in the bone, the significance of which is not yet clear.

Gcneral metabolism of $1,25-(\mathrm{OH})_{2} D_{3}$. The concentration of radioactivity in the plasma and tissues at various times after intravenous administration of $59.6 \pm 7.5$ pmoles of $\left[26,27-{ }^{3} \mathrm{H}\right]-1,25-(\mathrm{OH})_{2} \mathrm{D}_{3}$ to vitamin D-deficient rats on a low calcium diet is shown in Table V. As has been previously demonstrated in the chick (11), the dose disappears from the plasma very rapidly. Assuming the blood represents $6 \%$ of the total body weight, at $1 \mathrm{hr}$ after injection there is only $27.8 \pm 6.5 \%$ of the total dose in the plasma. The remainder of the dose appears distributed among the various tissues with the highest concentrations at $1 \mathrm{hr}$, appearing in the liver and intestine.

As has been mentioned previously, the intestine and bone radioactivity remain chloroform soluble up to 48 hr after dosage. This is in contrast to the other tissues studied where at $24 \mathrm{hr}$ there is up to $55 \%$ of the radioactivity present in the tissues found in the water layer after chloroform-methanol extraction. Also of interest is the apparent rebound of radioactivity in the bone, kidney, and muscle $24 \mathrm{hr}$ after dosage of $1,25-(\mathrm{OH})_{2} \mathrm{D}_{3}$. It is at this time that the radioactivity in the muscle and kidney becomes more water soluble while that found in the bone remains chloroform soluble but, as shown in $\mathrm{Ta}$ ble III, becomes less polar than the the $1,25-(\mathrm{OH})_{2} \mathrm{D}_{3}$.

When the radioactivity is extracted from the tissues and the lipid extracts applied to the Sephadex LH-20 columns, the metabolite picture shown in Table VI is obtained. The liver shows the fastest decrease in 1,25$(\mathrm{OH})_{2} \mathrm{D}_{3}$ with a corresponding increase in the watersoluble radioactivity. The intestine (Table I) and plasma show no metabolites less polar than $1,25-(\mathrm{OH})_{2} \mathrm{D}_{3}$. These less polar metabolites appear to concentrate in the bone (Table III) and muscle $24 \mathrm{hr}$ after dosage. 


\section{DISCUSSION}

The data presented in this report provide additional evidence that it is $1,25-(\mathrm{OH})_{2} \mathrm{D}_{3}$ itself and not a further metabolite which is responsible for the observed stimulation in intestinal calcium transport. In contrast to the chick (11), further metabolites do appear in the intestine of rats. However, their concentrations are relatively low and they appear to reach a maximum at $12-24 \mathrm{hr}$ after administration of the $1,25-(\mathrm{OH})_{2} \mathrm{D}_{3}$ long after the transport system has responded maximally.

The bone calcium mobilization response to 60 pmoles $1,25-(\mathrm{OH})_{2} \mathrm{D}_{3}$ was, as might be expected, similar to that noted for rats injected with 650 pmoles of $1,25-(\mathrm{OH})_{2} \mathrm{D}_{3}$ (13). The peculiar $48 \mathrm{hr}$ maximum in the bone calcium mobilization response of vitamin D-deficient rats to a 65 pmole intrajugular injection of $1,25-(\mathrm{OH})_{2} \mathrm{D}_{3}$ as reported earlier (9) was not observed. The difference between the two sets of data has not yet been explained. However, using the bone calcium mobilization response obtained under the conditions reported in this paper, it is apparent that from 1 to $12 \mathrm{hr}$ after dosage, that is when the system is being maximally stimulated, $1,25-(\mathrm{OH})_{2} \mathrm{D}_{3}$ is the major metabolite present in the bone. As the bone calcium mobilization response begins to decrease at $24 \mathrm{hr}$, there is a corresponding decline in the per cent of the bone radioactivity appearing as $1,25-(\mathrm{OH})_{2} \mathrm{D}_{3}$ and an increase in radioactivity in the regions of the column both less and more polar than $1,25-(\mathrm{OH})_{2} \mathrm{D}_{8}$. Since these metabolites appear to the greatest extent at the time when the bone calcium mobilization response is beginning to decline, it seems unlikely that they are responsible for the response observed as early as $6 \mathrm{hr}$ after dosage of $1,25-(\mathrm{OH})_{2} \mathrm{D}_{3}$. It therefore appears that 1,25 $(\mathrm{OH})_{2} \mathrm{D}_{3}$ is the most likely candidate for the active form of vitamin $\mathrm{D}$ responsible for the bone calcium mobilization in the rat.

Supporting these views is the observation that at 24 $\mathrm{hr}$ after dosage, when intestinal transport is still being strongly stimulated, $84 \pm 7 \%$ of the radioactivity in the intestine is present as $1,25-(\mathrm{OH})_{2} \mathrm{D}_{3}$. In the other tissues at this time, the amount of $1,25-(\mathrm{OH})_{2} \mathrm{D}_{3}$ present varies from 9 to $48 \%$ of the homogenate radioactivity. It therefore appears that the intestine is concentrating the 1,25$(\mathrm{OH})_{2} \mathrm{D}_{3}$ in order to maintain a high calcium transport ratio. In contrast, the bone, whose $1,25-(\mathrm{OH})_{2} \mathrm{D}_{2}$ level has fallen to values similar to the surrounding tissues, also shows a corresponding drop in its mobilization response.

The water-soluble radioactivity which appeared in the kidney, liver, and bile of the chick after intrajugular injection of $1,25-(\mathrm{OH})_{2} \mathrm{D}_{3}(11)$ also makes its appearance in the kidney, liver, muscle, and plasma of the rat. From the fact that this water-soluble radioactivity is found to the largest extent in those tissues (liver, kidney) normally involved in the removal of compounds from the body, it seems possible that it represents compounds which are being prepared for excretion into urine or feces. However, at this time, other physiologically sig-

TABLE V

Distribution of Radioactivity in Plasma and Tissues after an Injection of [26,27-3 $\mathrm{H}]-1,25$-Dihydroxycholecalciferol

\begin{tabular}{|c|c|c|c|c|c|c|}
\hline & Intestine & Bone & Kidney & Plasma & Liver & Muscle \\
\hline \multicolumn{7}{|l|}{$1 \mathrm{Hr}$ after dose } \\
\hline$\%$ Dose/g tissue & 2.7 & 1.6 & 2.3 & $6.4 \pm 1.6 \ddagger$ & 3.8 & 1.1 \\
\hline$\%$ Chloroform soluble & 112 & 103 & 102 & 108 & 104 & 87 \\
\hline \multicolumn{7}{|l|}{$7 \mathrm{Hr}$ after dose } \\
\hline$\%$ Dose $/ \mathrm{g}$ tissue & $3.0 \pm 0.8$ & 1.2 & 1.6 & $2.3 \pm 0.3$ & 1.5 & 0.5 \\
\hline$\%$ Chloroform soluble & $97 \pm 2$ & 91 & 83 & 91 & 67 & 80 \\
\hline \multicolumn{7}{|l|}{$12 \mathrm{Hr}$ after dose } \\
\hline \% Dose/g tissue & 1.7 & 1.0 & 1.0 & $1.6 \pm 0.4$ & 1.2 & 0.2 \\
\hline$\%$ Chloroform soluble & 87 & 103 & 87 & 72 & 58 & 83 \\
\hline \multicolumn{7}{|l|}{$24 \mathrm{Hr}$ after dose } \\
\hline$\%$ Dose/g tissue & $2.1 \pm 0.1$ & $2.4 \pm 0.4$ & $1.5 \pm 0.2$ & $1.1 \pm 0.1$ & $1.0 \pm 0.05$ & 1.0 \\
\hline$\%$ Chloroform soluble & $95 \pm 10$ & $94 \pm 1$ & $45 \pm 10$ & $61 \pm 1$ & $54 \pm 2$ & 59 \\
\hline \multicolumn{7}{|l|}{$48 \mathrm{Hr}$ after dose } \\
\hline \% Dose/g tissue & 0.7 & 0.3 & - & $0.6 \pm 0.1$ & - & - \\
\hline \% Chloroform soluble & 93 & 88 & - & 73 & - & - \\
\hline
\end{tabular}

For each time point, three to five vitamin D-deficient rats on a low calcium diet were dosed intrajugularly with $59.6 \pm 7.5$ pmoles of $\left[26,27-{ }^{3} \mathrm{H}\right]-1,25-(\mathrm{OH})_{2} \mathrm{D}_{3} \cdot{ }^{*}$ At the times indicated, the rats were killed and the tissues under study were collected and pooled for each group. They were then analyzed as described in the text.

* 1,25- $(\mathrm{OH})_{2} \mathrm{D}_{3}, 1,25$-dihydroxycholecalciferol.

¥ Standard deviation. 
TABLE VI

Metabolites in Plasma and Tissues after Injection of $\left[26,27-{ }^{3} \mathrm{H}\right]-1,25-D$ ihydroxycholecalciferol

\begin{tabular}{|c|c|c|c|c|}
\hline & \multicolumn{4}{|c|}{ Metabolites } \\
\hline & Kidney & Plasma & Liver & Muscle \\
\hline & \multicolumn{4}{|c|}{$\%$ of homogenate radioactivity } \\
\hline $1 \mathrm{Hr}$ after dose & & & & \\
\hline Less polar than $1,25-(\mathrm{OH})_{2} \mathrm{D}_{3}{ }^{*}$ & 1.7 & 一 & 2.5 & 5.1 \\
\hline $1,25-(\mathrm{OH})_{2} \mathrm{D}_{3}{ }^{*}$ & 94 & 93 & 77 & 75 \\
\hline More polar than $1,25-(\mathrm{OH})_{2} \mathrm{D}_{3}{ }^{*}$ & 2.4 & - & 2.9 & - \\
\hline Column strip & 2.0 & 0.3 & 2.7 & 1.6 \\
\hline $\mathrm{H}_{2} \mathrm{O}$ soluble & 0 & 0 & 0 & 13 \\
\hline Total recovery & 100.1 & 93.3 & 85.1 & 94.7 \\
\hline \multicolumn{5}{|l|}{$7 \mathrm{Hr}$ after dose } \\
\hline Less polar than $1,25-(\mathrm{OH})_{2} \mathrm{D}_{3}{ }^{*}$ & 3.0 & - & 4.8 & 4.0 \\
\hline $1,25-(\mathrm{OH})_{2} \mathrm{D}_{3} *$ & 68 & 73 & 49 & 55 \\
\hline More polar than $1,25-(\mathrm{OH})_{2} \mathrm{D}_{3}{ }^{*}$ & 1.9 & 3.6 & 3.4 & 1.7 \\
\hline Column strip & 1.8 & 0.4 & 4.0 & 2.2 \\
\hline $\mathrm{H}_{2} \mathrm{O}$ soluble & 17 & 9.0 & 33 & 20 \\
\hline Total recovery & 91.7 & 86.0 & 94.2 & 82.9 \\
\hline \multicolumn{5}{|l|}{$12 \mathrm{Hr}$ after dose } \\
\hline Less polar than $1,25-(\mathrm{OH})_{2} \mathrm{D}_{3}{ }^{*}$ & 1.7 & - & 5.1 & 5.2 \\
\hline $1,25-(\mathrm{OH})-\mathrm{D}_{3}^{*}$ & 78 & 45 & 35 & 61 \\
\hline More polar than $1,25-(\mathrm{OH})_{2} \mathrm{D}_{3}{ }^{*}$ & 3.1 & 5.4 & 4.0 & 3.6 \\
\hline Column strip & 1.9 & 0.6 & 2.1 & 1.8 \\
\hline $\mathrm{H}_{2} \mathrm{O}$ soluble & 13 & 28 & 42 & 17 \\
\hline Total recovery & 97.7 & 79.0 & 88.2 & 88.6 \\
\hline \multicolumn{5}{|l|}{$24 \mathrm{Hr}$ after dose } \\
\hline Less polar than $1,25-(\mathrm{OH})_{2} \mathrm{D}_{3}{ }^{*}$ & $1.2 \pm 1.2 \ddagger$ & - & $9.2 \pm 0.2$ & 37 \\
\hline $1,25-(\mathrm{OH})_{2} \mathrm{D}_{3}{ }^{*}$ & $31 \pm 7$ & $48 \pm 3$ & $22 \pm 3$ & 9.0 \\
\hline More polar than $1,25-(\mathrm{OH})_{2} \mathrm{D}_{3}{ }^{*}$ & $3.2 \pm 1.0$ & $8.7 \pm 2.1$ & $4.9 \pm 0.7$ & 2.5 \\
\hline Column strip & $3.1 \pm 0.4$ & $1.0 \pm 0.7$ & $2.9 \pm 0.6$ & 4.6 \\
\hline $\mathrm{H}_{2} \mathrm{O}$ soluble & $55 \pm 10$ & $39 \pm 1$ & $46 \pm 2$ & 41 \\
\hline Total recovery & $88.1 \pm 4.2$ & $96.7 \pm 6.7$ & $82.9 \pm 3.1$ & 94.1 \\
\hline
\end{tabular}

The animals were treated as described in Table $\mathrm{V}$.

* 1,25- $(\mathrm{OH})_{2} \mathrm{D}_{3}, 1,25$-dihydroxycholecalciferol.

‡ Standard deviation.

nificant roles for these radioactive compounds cannot be ruled out. Further work must be done to determine the importance of the water-soluble radioactivity and of both the radioactivity that is less polar and more polar than the $1,25-(\mathrm{OH})_{2} \mathrm{D}_{3}$.

It is of interest that although $1,25-(\mathrm{OH})_{2} \mathrm{D}_{3}$ is in the intestine $1 \mathrm{hr}$ after dosage, the intestinal calcium transport response has not yet been stimulated (Fig. 2). In rats, the intestinal calcium transport response to 1,25 $(\mathrm{OH})_{2} \mathrm{D}_{3}$ is not blocked by actinomycin $\mathrm{D}$ which suggests transcription of genetic information is not involved (10). The lag which obviously exists may mean that a transport system may be assembled from existing but unread messenger RNA's or from precursor components. It seems unlikely that there is a direct involvement of $1.25-(\mathrm{OH})_{2} \mathrm{D}_{3}$ in the transport mechanism per se simply because of the lag. The response of bone to $1,25-(\mathrm{OH})_{2} \mathrm{D}_{3}$ is actinomycin sensitive which suggests that RNA and protein synthesis is involved in this mechanism (13). In any case, it seems that the $1,25-(\mathrm{OH})_{2} \mathrm{D}_{3}$ will be of great value in unraveling the mechanisms involved.

\section{ACKNOWLEDGMENTS}

This work was supported by grants from the National Institutes of Health No. AM14881 and Training Grant No. GM00236 BCH and by the Harry Steenbock Research Fund.

\section{REFERENCES}

1. Lund, J., and H. F. DeLuca. 1966. Biologically active metabolite of vitamin $\mathrm{D}_{3}$ from bone, liver, and blood serum. J. Lipid Res. 7 : 739.

2. Blunt, J. W., H. F. DeLuca, and H. K. Schnoes. 1968. 25-Hydroxycholecalciferol. A biologically active metabolite of vitamin $\mathrm{D}_{3}$. Biochemistry. $7: 3317$.

3. Fraser, D. R., and E. Kodicek. 1970. Unique biosynthesis by kidney of a biologically active vitamin $\mathrm{D}$ metabolite. Nature (Lond.). 228: 764. 
4. Gray, R., I. Boyle, and H. F. DeLuca. 1971. Vitamin $\mathrm{D}$ metabolism: the role of kidney tissue. Science (Wash. D.C.). $172: 1232$.

5. Holick, M. F., H. K. Schnoes, and H. F. DeLuca. 1971. Identification of 1,25-dihydroxycholecalciferol, a form of vitamin $\mathrm{D}_{3}$ metabolically active in the intestine. Proc. Natl. Acad. Sci. U. S. A. 68: 803.

6. Holick, M. F., H. K. Schnoes, H. F. DeLuca, T. Suda, and $R$. J. Cousins. 1971. Isolation and identification of 1,25-dihydroxycholecalciferol. A metabolite of vitamin D active in intestine. Biochemistry. 10: 2799.

7. Lawson, D. E. M., D. R. Fraser, E. Kodicek, H. R Morris, and D. H. Williams. 1971. Identification of 1,25dihydroxycholecalciferol, a new kidney hormone controlling calcium metabolism. Nature (Lond.). 230: 228.

8. Haussler, M. R., D. W. Boyce, E. T. Littledike, and H. Rasmussen. 1971. A rapidly acting metabolite of vitamin $\mathrm{D}_{3}$. Proc. Natl. Acad. Sci. U. S. A. 68: 177.

9. Omdahl, J., M. Holick, T. Suda, Y. Tanaka, and H F. DeLuca. 1971. Bio'ogical activity of 1,25-dihydroxycholecalciferol. Biochemistry. 10: 2935.

10. Tanaka, Y., H. F. DeLuca, J. Omdahl, and M. F. Holick. 1971. Mechanism of action of 1,25-dihydroxycholecalciferol on intestinal calcium transport. Proc. Natl. Acad. Sci. U. S. A. 68: 1286 .

11. Frolik, C. A., and H. F. DeLuca. 1971. 1,25-Dihydroxycholecalciferol: the metabolite of vitamin $\mathrm{D}$ responsible for increased intestinal calcium transport. Arch. Biochem. Biophys. 147: 143.

12. Boyle, I. T., L. Miravet, R. W. Gray, M. F. Holick, and H. F. DeLuca. 1972. The response of intestinal calcium transport to 25-hydroxy and 1,25-dihydroxy vitamin D in nephrectomized rats. Endocrinology. 90: 605.

13. Tanaka, Y., and H. F. DeLuca. 1971. Bone mineral mobilization activity of 1,25-dihydroxycholecalciferol, a metabolite of vitamin D. Arch. Biochem. Biophys. 146: 574.

14. Raisz, L. G., C. L. Trummel, M. F. Holick, and H. F. DeLuca. 1972. 1,25-Dihydroxycholecalciferol: a potent stimulator of bone resorption in tissue culture. Science (Wash. D. C.). $175: 768$.

15. Holick, M. F., M. Garbedian, and H. F. DeLuca. 1972. 1,25-Dihydroxycholecalciferol: metabolite of vitamin $\mathrm{D}_{3}$ active on bone in anephric rats. Science (Wash. D. C.). $176: 1146$.

16. Suda, T., H. F. DeLuca, and Y. Tanaka. 1970. Biological activity of 25 -hydroxyergocalciferol in rats. J. Nutr. 100: 1049 .

17. Suda, T., H. F. DeLuca, and R. B. Hallick. 1971. Synthesis of $\left[26,27-{ }^{8} \mathrm{H}\right]-25$-hydroxycholecalciferol. Anal. Biochem. 43: 139 .

18. Martin, D. L., and H. F. DeLuca. 1969. Influence of sodium on calcium transport by the rat small intestine. Am. J. Physiol. 216: 1351 . 